\title{
Metacognition and Self-regulated Learning in Predicting University Students' Academic Achievement in Turkey ${ }^{*}$
}

\author{
Barış Çetin \\ Correspondence: Barış Çetin, Ph.D. Çanakkale 18 Mart Üniversitesi Eğitim Fakültesi, Turkey. \\ Received: February 17, 2017 \\ Accepted: March 7, 2017 Online Published: March 10, 2017 \\ doi:10.11114/jets.v5i4.2233 \\ URL: https://doi.org/10.11114/jets.v5i4.2233
}

\begin{abstract}
The purpose of this study was to determine whether perceived levels of self-regulated learning and metacognition predicted the ultimate grade point average (GPA) attained by 206 female and 70 male college seniors (aged 21 to 27) finishing their elementary education teaching certification studies at a university in Turkey. Data regarding individual levels of metacognition were collected through the administration of the "Metacognitive Skills Inventory for Adults" (Schraw \& Dennison, 1994) and translated to Turkish by Ozcan (2007). A separate scale authored by Turan (2009) was administered to the same set of participants to obtain levels of perceived self-regulated learning. Findings indicated that students' self-regulated learning and metacognition total scores correlated with each other but neither scale was predictive of the students' GPAs at a significant level in the hypothesized positive direction. Interestingly, selfregulated learning scores were significantly related to GPA but in a negative direction.
\end{abstract}

Keywords: university student, metacognition, self-regulated learning, grade point average, GPA

\section{Introduction}

The ideas that later encompassed the term metacognition were first suggested at the beginning of the $20^{\text {th }}$ Century by William James, Jean Piaget, Lev Vygotsky and John Dewey (Flavell \& Quirk, 2006). John Flavell began to use the term metacognition in the late 1970s and defined it as cognitive activity regulating any particular dimension of a certain cognitive activity (Flavell, 1977; Flavell, Miller, \& Miller, 2002). Metacognition is often thought of as "thinking about thinking" (Flavell, 1979, p.906). Metacognition differs from cognition in that cognitive skills are needed to fulfil assigned tasks whereas metacognition is required to be able to comprehend how certain tasks are fulfilled (Garner, 1987; as cited by Schraw, 1998). Metacognition refers to the nature of humans and their differing characteristics of cognitive activities concerning possible strategies that may be helpful for achieving different tasks. Metacognition refers not only to one's actual knowledge, but also one's ability to apply that knowledge to new situations in order to come up with new solutions when strict application of specific knowledge fails (Armbruster, Echolsand, \& Brown, 1983).

Metacognition is generally further grouped into two aspects of the concept; the knowledge of cognition and the regulation of cognition (Bruning, Schraw, \& Ronning, 1999). Knowledge of cognition has been defined as knowledge that has been memorized regarding the goals and strategies of individuals in their efforts to accomplish tasks (Desoete \& Veenman, 2006). Knowledge of cognition can further be thought of as involving declarative, procedural, and conditional types of knowledge (Schraw \& Moshman, 1995). Declarative knowledge concerns knowledge of certain things. Procedural knowledge involves knowing about how to do such things. Conditional knowledge involves having knowledge regarding "why" and "when" such procedures and things may be utilized (Schraw, 1998). As a whole, knowledge of cognition constitutes the basis for one's belief as to which type of interactions, actions and/or factors (such as studying for example) can lead to the desired outcomes of cognitive effort (Flavell, 1979).

The regulation of cognition consists of three elements: planning, regulation, and evaluation. Planning is related to performing activities related to background information. Regulation concerns the self-testing of skills needed to control learning and monitoring the effects of such testing. Evaluation concerns an individual's evaluations regarding product information received as a consequence of his or her regulations regarding the learning process (Bruning, Schraw, \& Ronning, 1999).

\footnotetext{
* Learning Together Conference May 21, 2016 Multiculturalism Education in Canada Faculty of Education, Simon Fraser University and this is the extended version of the article of which summary was published.
} 
A related concept is that of self-regulated learning. The aim of self-regulated learning (SRL) is to facilitate life-long learning skills. Self-regulated learning (SRL) has been defined as the feelings and actions that indicate a tendency to achieve individuals' goals (Zimmerman \& Schunk, 1989). SRL is an active, constructive process whereby learners set goals for their learning and then attempt to monitor, regulate, and control their cognition, motivation, and behaviour (Pintrich, 2000). Studies carried out that focus on self-regulated learning began in the mid-1980's and focused on ways of supporting one's own ability to actively engage in one's own learning process (Zimmerman, 2001).

The structure of the self-regulated learning process is broken into three phases: 1) the performance phase, 2) the self-reflection phase and 3) the forethought phase (Zimmerman, 2002; Zimmerman \& Schunk, 2004). The performance phase consists of a self-control segment and a self-observation segment. During this first phase, an individual uses a specific selected method based on his/her personal reflections on their past performances (self-control segment). Self-observation is then utilized as one self-tests their chosen method in reference to the method's success at producing the desired results (Zimmerman, 2002). The Self-control segment of the self-reflection phase helps individuals to focus on the task and optimize their effort. Self-control involves the use of self-instruction, imagery, attention focusing, and task specific strategies (Schunk, 1982, cite by Zimmerman, 2000).

The self-reflection phase is a self-regulatory process consisting of self-judgment and self-reaction segments (Bandura, 1986). Self-judgment influences the importance one gives to fulfilling one's goal (Zimmerman, 1994). One conducts a self-evaluation evaluating the temporal importance of one's performance and relevant results (Zimmerman, 2012). Self-reaction concerns the use of the personal evaluation of one's own performance and then considering appropriate changes in such learners' performances and judgments regarding their tasks to best meet the desired outcomes (Pintrich, 2010).

The forethought phase involves task analysis and self-motivation beliefs. Task analysis includes goal setting and strategic planning (Zimmerman, 2002). Task analysis also involves decomposing a learning task and its context into constituent elements and then constructing a personal strategy from prior knowledge of these elements (Winne \& Hadwin, 1998; as cited by Zimmerman \& Moylan, 2009, p. 301). Self-motivation comes from individuals' beliefs regarding their learning, such as their personal self-efficacy beliefs regarding their own capabilities to learn and from their own outcome expectations related to past consequences of learning (Bandura, 1997). Self-motivation and outcome expectancies are beliefs regarding one's performances, such as being socially recognized or obtaining valued employment (Zimmerman \& Moylan, 2009).

For the purposes of the current study, relationships between metacognition and self-regulated learning are relevant. Self-regulated learning and metacognition are both generally defined by their component parts (Sperling, Howard, Staley \& DuBois, 2004; Tarricone, 2011). Both include measuring the degrees to which individuals are metacognitively, motivationally, and behaviourally active participants in their own learning processes (Zimmerman, 1989). Like metacognition, self-regulated learning includes controlling, self-monitoring, self-evaluating, and self-instruction (Baumeister \& Vohs, 2004; Zimmerman \& Schunk, 2001; as cited by Amir Kiaei, 2014). Self regulated learning refers to learners' opportunities to metacognitively monitor properties of information, declarative and procedural knowledge, and their cognitive experience (Winne, 2011, p. 21). These concepts are inter-related. Previous studies have shown that general academic averages can predict levels of self-regulated learning (Bozpolat, 2016) and that the use of metacognitive skills are positively correlated to academic achievement in various disciplines (Hakan, 2016). While some evidence exists to support the hypothesis that SRL and metacognitive abilities relate to ultimate academic achievement, the interdependency of both and any possible impact on the grade point average (GPA)s of final year pre-service elementary teaching candidates in Turkey has yet to be considered.

This study is intended to fill the gap that exists with regard to investigations that examine the impact of both self-regulated learning and metacognition on the GPA of college students. This study contributes to the understanding of any predictive relationship that may exist between both SRL and metacognitive abilities on GPA. Better understanding any relationships between or withing these concepts is likely to increase the quality of preservice teacher training if such concepts are related to the ultimate achievement of students within any teacher education program. The purpose of this study is to investigate if metacognition and self-regulated learning together predict GPAs of students who study within the department of elementary education in the Faculty of Education at a university in Turkey. Two primary research questions included:

1) What is the relationship between self-regulated learning and metacognition to students' GPAs?

2) Do the students' scores taken from the scales of metacognition and self-regulation learning predict participating student GPAs? 


\section{Methods}

Prediction studies show how a variable is predicted by another variable using correlation coefficients (Creswell, 2008). The model of this study is a prediction study since the aim was to determine if any predictive relationships existed between metacognition and self-regulation learning together on the ultimate GPA of elementary education pre-service teachers in their final year of teacher preparation at a university in Turkey.

\subsection{Participants}

The sampling of the study consisted of 276 students in total (206 female and 70 male; ages 21 to 27) enrolled in the 2014-2015 winter and spring semesters at the Canakkale 18 March University Education Faculty, Elementary Education program. Participant volunteers were in their final year of studies in the elementary teacher preparation program.

\subsection{Instruments}

Data were gathered by administering the "Metacognitive Skills Inventory for Adults", the "Self-regulated Learning Perception Scale" and a "Personal Information Form" face-to-face with the volunteer participants studying at the Department of Elementary Education within the Faculty of Education at Canakkale 18 Mart University in the winter and spring semesters of the 2014-2015 academic year.

To measure self-reported metacognitive skill levels of the teacher candidates, the "Metacognitive Skills Inventory for Adults" (MSIA), developed by Schraw and Dennison (1994) and translated into Turkish (Schraw \& Dennison, 1994; Özcan, 2007) was used in this study. The inventory consists of 52 questions divided into two subscales: awareness of cognitive characteristics (17 questions) and regulation of cognitive skills (35 questions). The MSIA utilizes a five point Likert scale rating system for each of the 52 questions on the instrument. An answer of "Always False" received a score of 1 where as an answer of "Always True" received a score of 5 to reflect the minimum and maximum scores a participant could receive on the instrument. "Sometimes False", "Neutral" and "Sometimes True" received a score of 2, 3 , and 4 respectively. For each participant, the scores for their answers on the 52 questions of the instrument were summed to obtain a total metacognitive skills scale score for use in analysis. The Cronbach alpha reliability of the full inventory was .94 in a Turkish sample (Özcan, 2007).

The Self-regulated Learning Perception Scale (Turan, 2009) consists of 41 items representing four dimensions: motivation and action to learning (7 questions), planning and goal setting (8 questions), strategies for learning and assessment (9 questions), and lack of self-directedness (7 questions). The items were answered through a five-point Likert scale and assigned a value from one to five. Item scores were summed to obtain sub-dimensions and total scores for each participant. When the total score is considered, the minimum score is 41 and the maximum score is 205 . Cronbach's alpha values of the subscales were 0.88, 0.91, 0.83, and 0.76, respectively (Turan, Demirel \& Sayek, 2009).

Data on GPA were collected according to the students' self-report. The GPA for the participants was calculated using the average of the student's grades for all courses beginning from the first through the sixth semester of coursework at Çanakkale 18 Mart University's Elementary Education Department. GPA was self-reported by each participant within the Personal information form that was completed just prior to completing the MSIA and the Self-regulated Learning Perception Scale. The information form consisted of general demographic questions conserning the participant including participant GPA, age, gender and year of study.

\subsection{Data Analysis}

Multiple regression is typically used to examine any predictive relationships between at least two predictor variables and a criterion variable (Fraenkel \& Wallen, 2006). Therefore, multiple regression analysis was applied in this study. Additionally, Pearson Product-Moment correlation analysis was used to reveal any relationship between GPA and scores obtained from the Self-regulated Learning Perception Scale and the Metacognitive Skills Inventory for Adults. Whereas multiple regression analysis was used for determining whether the Self-regulated Learning Perception Scale and the Metacognitive Skills Inventory for Adults together predict GPA, the Pearson Product-Moment correlation coefficient analysis was used to examine to what extent each of the three scales (GPA, SRL \& metacognitive scale) related to each other.

\section{Results}

In this section, the results of the Pearson Product-Moment Correlation carried out to examine any possible correlations between elementary education students' metacognition total scores and sub factors scores; self-regulated learning total scores and sub factors scores (examined separately with regard to student participants' GPAs) are provided. In addition, the results of the multiple regression analysis conducted to examine elementary education students' metacognition total scores and sub factors scores; self-regulated learning total scores and sub factors scores (combined) predicted GPAs, are given. Table 1 provides descriptive statistics and Pearson product-moment correlations. 
Table 1. Means, standard deviations and inter-correlations between self-regulated learning, metacognition, and GPA

\begin{tabular}{|c|c|c|c|c|c|c|c|c|c|c|c|}
\hline & $\mathrm{M}$ & SD & 1 & 2 & 3 & 4 & 5 & 6 & 7 & 8 & 9 \\
\hline GPA & 2.6888 & .35066 & 1 & -.055 & -.090 & -.113 & -.052 & $-.124 *$ & -.043 & -.030 & -.035 \\
\hline $\begin{array}{l}\text { Motivation and action } \\
\text { to learning }\end{array}$ & 3.9581 & .55544 & -.055 & 1 & $.623^{* *}$ & $.586^{* *}$ & .006 & .693 & .642 & $.652^{* *}$ & $.663^{* *}$ \\
\hline $\begin{array}{l}\text { Planning and goal } \\
\text { setting }\end{array}$ & 3.9588 & .51029 & -.090 & $.623^{* *}$ & 1 & $.650^{* *}$ & -.003 & .730 & $.592^{* *}$ & .650 & $.645^{* *}$ \\
\hline $\begin{array}{l}\text { Strategies for learning } \\
\text { and assessment }\end{array}$ & 4.0246 & .54071 & -.113 & $.586^{* *}$ & $.650^{* *}$ & 1 & $.368^{* *}$ & .952 & $.616^{* *}$ & $.675^{* *}$ & .670 \\
\hline $\begin{array}{l}\text { Lack } \\
\text { self-directedness }\end{array}$ & 3.0994 & .94031 & -.052 & .006 & -.003 & $.368^{* *}$ & 1 & .485 & -.020 & .017 & $.005^{* *}$ \\
\hline $\begin{array}{l}\text { Self-regulation total } \\
\text { scores }\end{array}$ & 3.7923 & .44972 & $-.124^{*}$ & $.693^{* *}$ & $.730^{* *}$ & $.952^{* *}$ & $.485^{* *}$ & 1 & $.627^{* *}$ & $.680^{* *}$ & $.677^{* *}$ \\
\hline $\begin{array}{l}\text { Knowledge } \\
\text { cognition }\end{array}$ & 3.8321 & .52912 & -.043 & $.642^{* *}$ & $.592^{* *}$ & $.616^{* *}$ & -.020 & .627 & 1 & $.902^{* * *}$ & $.956^{* *}$ \\
\hline $\begin{array}{l}\text { Regulation } \\
\text { cognition }\end{array}$ & 3.8081 & .50478 & -.030 & $.652^{* *}$ & $.650^{* *}$ & $.675^{* *}$ & .017 & .680 & $.902^{* *}$ & 1 & $.989^{* *}$ \\
\hline $\begin{array}{l}\text { Metacognition total } \\
\text { scores }\end{array}$ & 3.8159 & .50133 & -.035 & $.663^{* *}$ & $.645^{* *}$ & $.670^{* * *}$ & .005 & .677 & $.956^{* *}$ & $.989^{* * *}$ & 1 \\
\hline
\end{tabular}

* Correlation is significant at the 0.05 level (2-tailed).

** Correlation is significant at the 0.01 level (2-tailed).

As can be seen in Table 1, the GPAs of students significantly and negatively correlated with self-regulated learning total scores $(\mathrm{p}<.05)$. The GPAs of students did not significantly correlate with metacognition total scores. There were statistically significant correlations between metacognition and self-regulation learning total scores $(\mathrm{p}<.01)$.

Table 2. Results of the multiple regression analysis regarding the prediction of GPAs by metacognition and self-regulation learning

\begin{tabular}{|c|c|c|c|c|c|c|c|c|}
\hline & $\mathrm{B}$ & Std. Error & Beta & $\mathrm{t}$ & Sig. & Zero-order & Partial & Part \\
\hline (Constant) & 2.951 & .194 & & 15.180 & .000 & & & \\
\hline Motivationandactiontolearning & .296 & .119 & .469 & 2.494 & .013 & -.055 & .151 & .149 \\
\hline Planningandgoalsetting & .282 & .135 & .410 & 2.085 & .038 & -.090 & .126 & .124 \\
\hline Strategiesforlearningandassessment & .765 & .315 & 1.180 & 2.427 & .016 & -.113 & .147 & .145 \\
\hline Lackofselfdirectedness & .221 & .085 & .593 & 2.605 & .010 & -.052 & .157 & .155 \\
\hline Selfregulationtotatlscores & -1.743 & .628 & -2.235 & -2.773 & .006 & -.124 & -.167 & -.165 \\
\hline Knowledgeofcognition & -.047 & .139 & -.072 & -.342 & .733 & -.043 & -.021 & -.020 \\
\hline
\end{tabular}

$\mathrm{R}=.218, \mathrm{R}^{2}=.048$

$\mathrm{F}_{(7-275)=} 1.914, \mathrm{p}>.005$

A multiple regression analysis, presented in Table 2, was computed to investigate how metacognition and self-regulated

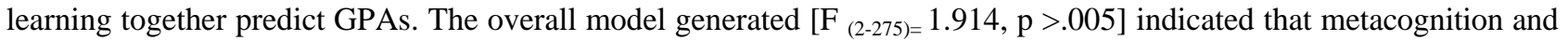
self-regulation learning total scores together did not predict students' GPAs. Total scores obtained from the metacognition and self-regulated learning scales together explained .048\% of the variance in GPAs.

\section{Discussion}

Does one's abilities within the skill areas defined within both metacognition and self-regulated learning predict one's ultimate GPA? Regarding the present study, the answer regarding this possible predictive relationship for pre-service teachers in one Turkish university would appear to be no. The summed scores of pre-service teachers taking the MSIA and the Self-regulated Learning Perception Scale did not show to be predictive of student grade point averages.

Within this study, do metacognition scores correlate with participant GPAs? Again, the answer regarding the sample in the present work would appear to be no. This finding supports the work of Sarwar (2009) which found no relationship between metacognition and academic achievement. This result contradicts the findings of Shih Hsu (1997) who found that student metacognitive scores were negatively correlated with academic achievement scores. More recently Guzel (2011) as well as Gul and Shehzad (2012) found a low but significant correlation between metacognition and achievement scores. Clearly, some variation exists within current literature regarding any link between student GPA's and metacognitive practices.

Regarding self-regulated learning, the present study found a significant correlation in a negative direction between self-regulated learning and student GPAs. This indicates that as one's self-regulated learning skills increase and are used more often, GPA is diminished. This finding would seem counter intuitive and contradicts a study by Heikkilä and Lonka (2006) who discovered a weak, positive relationship between academic average and self-regulated learning. This 
also contradicts the work of Gaythwaite (2006) who reported a significant positive relationship between achievement and self-regulated learning and Fallon (2006) that found self-regulated learning were significant predictors of the variance in GPA.

Metacognition has been identified as a strong predictor of learning (Coutinho, 2007) and Mega, Ronconi and De Beni (2013) determined that self-regulated learning positively predicts academic achievement. Logically then, one may feel that the negative findings in the hypothesised positive correlations between metacognitive skills, self-regulated learning skills and ultimate GPA in the current study might be counter intuitive. Results of the current work suggest that perhaps one or more specific circumstances experienced by student participants within the Turkish university of focus may have an influence on this study's results.

\section{Limitations and Further Study}

A clear limitation to the present findings is that the sample participants in this study were all from one teacher education program at one Turkish University. Results of the present work cannot generalize to other locations or populations. This limitation, however, shines some light on how different locations and populations may influence any relationships between metacognitive skills, self-regulated learning and measured values of academic achievement.

One possible consideration might be that within the studied Turkish university's teacher education program, GPA is not considered when choosing candidates for the program. Students are rather accepted into the teacher education program based on a separate "Bachelor Placement Exam" (LYS). Additionally, entry into the teacher education is not restricted to one undergraduate major. Instead, undergraduate students from many academic departments at the studied university may apply to the teacher education programs offered by the Faculty of Education. These realities may provide one possible explanation to be studied. Since GPA is not a factor in a student's goal to become a teacher candidate within the Faculty of Education at the studied university, perhaps little effort is placed in achieving a high GPA during one's undergraduate studies. Further study should be conducted to explore this possibility.

Another possible influence may reside in the ways in which newly graduated teachers are chosen to work in Turkey's public schools. Here again, GPA is not considered when public schools choose teachers to fill vacancies at local public schools. Rather than GPA, schools use scores from the Public Personnel Selection Exam (KPSS) as a key deciding factor as to ranking of the best teachers available. Again, GPA is not a valued measure of competence regarding a student's life goals. Here again, this is an area that requires further study.

Future researchers should focus on exploring any correlations and/or predictive relationships between metacognitive skills, self-regulated learning and the prior mentioned LYS and the KPSS. These two high stakes tests may answer the question prompted by the present work as to if the use of the outcome measure being used as the dependent variable is a factor in any relationships found.

\section{References}

Amir, K. Y. (2014). The relationship between metacognition, self-actualization, and well-being among university students: Reviving self-actualization as the purpose of education (Unpublished doctoral dissertation, Florida International University, Miami, Florida, U.S.A.). Retrieved from http://search.proquest.com.proxy.lib.sfu.ca/

Armbruster, B. B., Echolsand, C. H., \& Brown, A. L. (1983). The role of metacognition in reading to learn: A developmental perspective (Reading Education Report No. 40). Retrieved from: https://www.ideals.illinois.edu/bitstream/handle/2142/17499/ctrstreadeducrepv01983i00040_opt.pdf?sequence=1

Bandura, A. (1986). Social foundations of thought and action: A social cognitive theory. Englewood Cliffs, NJ: Prentice-Hall.

Bandura, A. (1997). Self-efficacy: The exercise of control. W.H. Freeman: New York.

Baumeister, R. F., \& Vohs, K. D. (2004). Handbook of Self-Regulation: Research, Theory, and Applications. New York, NY: Guilford Press.

Bozpolat, E. (2016). Investigation of the Self-Regulated Learning Strategies of Students from the Faculty of Education Using Ordinal Logistic Regression Analysis, Educational Sciences: Theory \& Practice, 16(1), 301-318 doi: 10.12738/estp2016.1.0281

Bruning, R. H., Schraw, G. J., \& Ronning R. R. (1999). Cognitive psychology and instruction. (3th ed.). New Jersey: Prentice-Hall, Inc.

Coutinho, S. (2007). The relationship between goals, metacognition, and academic success, The Journal of Doctoral Research in Education, 7(1), Retrieved from http://www.educatejournal.org/index.php/educate/issue/view/23

Creswell, J. W. (2008). Educational research Planning, conducting, and evaluating quantitative and qualitative research. 
Pearson Merrill Prentice Hall, New Jersey.

Desoete, A., \& Veenman, M. (2006). Metacognition in mathematics: Critical issues on nature, theory, assessment and treatment. A. Desoete \& V. Veenman (Eds.), Metacognition in Mathematics Education (pp.1-10). New York: Nova Science Publishers.

Fallon, A. M. (2006). An Exploration of the Relationship Between Self-Regulated Learning and Cognitive Skills (Unpublished doctoral dissertation, University of California, Berkley; California, U.S). Retrieved from http://search.proquest.com.proxy.lib.sfu.ca/dissertations/docview/305364581/fulltextPDF/A5E6FD41762A4B24P $\mathrm{Q} / 1$ ? accountid=13800

Flavell, J. H. (1977). Cognitive development. New Jersey: Prentice-Hall, Inc.

Flavell, J. H. (1979). Metacognition and cognitive monitoring A new area of cognitive- developmental Inquiry, American Psychologist, 34 (10). https://doi.org/10.1037/0003-066X.34.10.906

Flavell, J. H., Miller, P. H., \& Miller, S. A. (2002). Cognitive development (4th ed.). New Jersey: Prentice Hall.

Flavell, J., \& Quirk, M. (2006). Metacognition in medical education: Keys to developing expertise. New York: Springer Publishing Company.

Fraenkel, J. R., \& Wallen, N. E. (2006). How to design and evaluate research in education. New York, NY: Mc Graw Hill Higher Education.

Garner, R. (1987). Metacognition and Reading Comprehension. Norwood, NJ: Ablex Publishing.

Gaythwaite, E. S. (2006). Metacognitive self-regulation, self-efficacy for learning and performance, and critical thinking as predictors of academic success and course retention among community college students enrolled in online, telecourse, and traditional public speaking courses (Unpublished doctoral dissertation, University of Central Florida, Orlando, USA). Retrieved from http://search.proquest.com.proxy.lib.sfu.ca/

Gul, F., \& Shehzad, S. (2012). Relationship between metacognition, goal orientation and academic achievement. Procedia-Social and Behavioral Sciences 47. https://doi.org/10.1016/j.sbspro.2012.06.914

Guzel, A. (2011). Rehberlik ve psikolojik danismnanlik ogrencilerin bilis üstü becerilerinin ceşitli değişkenler Bakimindan Karsilastirilmasi ve empati egilimleri Ile Olan Iliskisinin Incelenmesi (Unpublished Master Thesis). Ankara University, Ankara, Turkey.

Hakan, O. (2016). Evaluation of metacognitive competence of pre-service music teachers in terms of some variables, Educational Research and Reviews, 11(8), 713-720. doi: 10.5897/ERR2016.2666

Heikkilä, A., \& Lonka, K. (2006). Studying in higher education: students' approaches to learning, self-regulation, and cognitive strategies. Studies in Higher Education, 31(1). https://doi.org/10.1080/03075070500392433

Mega, C., Ronconi, L., \& De Beni, R. (2013). What Makes a Good Student? How Emotions, Self-Regulated Learning, and Motivation Contribute to Academic Achievement. American Psychological Association, 1(106), 121-131. https://doi.org/10.1037/a0033546

Özcan, Z. Ç. (2007). Sınıf öğretmenlerinin derslerinde biliş üstü beceri geliştiren stratejileri kullanma özelliklerinin incelenmesi (Unpublished doctoral dissertation). Marmara Üniversitesi, Istanbul, Türkiye.

Pintrich, P. R. (2010). The role of goal orientation in self regulated learning. In M. Boekaerts, P. R. Pintrich \& M. Zeidner (Eds.), Handbook of self-regulation (pp.451-502). Academic Press: San Diego.

Sarwar, M. (2009). Relationship between Achievement Goals, Meta-Cognition and Academic Success In Pakistan, Journal of College Teaching \& Learning, 6(5). Retrieved from http://cluteinstitute.com/ojs/index.php/TLC/article/view/1141/1125

Schraw, G. (1998). Promoting general metacognitive awareness, Instructional Science, 26. https://doi.org/10.1023/A:1003044231033

Schraw, G., \& Dennison, R. S. (1994). Assessing metacognitive awareness, Contemporary Educational Psychology, 19 , 460-475. https://doi.org/10.1006/ceps.1994.1033

Schraw, G., \& Moshman, D. (1995). Metacognitive theories, Educational Psychology Review, 7. https://doi.org/10.1007/BF02212307

Schunk, D. H. (1982). Verbal self-regulation as a facilitator of children's achievement and self-efficacy. Human Learning, I, 265-277.

Shih, H. J. T. (1997). Value, expectancy, metacognition, resource management, and academic achievement: A structural 
model of self-regulated learning in a distance education (Unpublished doctoral dissertation, University of Southern California, California, U.S.) Retrieved from http://search.proquest.com.proxy.lib.sfu.ca/

Sperling, R. A., Howard, B. C., Staley, R., \& DuBois, N. (2004). Metacognition and Self-Regulated Learning Constructs, Educational Research and Evaluation, 10(2). https://doi.org/10.1076/edre.10.2.117.27905

Tarricone, P. (2011). The taxonomy of metacognition. New York, NY: Psychology Press.

Turan S., Demirel Ö., \& Sayek İ. (2009). Metacognitive awareness and self-regulated learning skills of medical students in different medical curricula, Medical Teacher, 31. https://doi.org/10.3109/01421590903193521

Turan, S. (2009). Probleme dayali öğrenmeye iliskin tutumlar, ogrenme becerileri ve basari arasindaki ilişkiler (Unpublished doctoral dissertation). Hacettepe Universitesi, Ankara, Turkey.

Winne, P. H. (2011). A cognitive and metacognitive analysis of self- regulated learning. In B. J. Zimmerman and D. H. Schunk (Eds.), Handbook of self-regulation of learning and performance (pp. 15-32). New York: Routledge.

Winne, P. H., \& Hadwin, A. F. (1998). Studying as self-regulated engagement in learning. In D. Hacker, J. Dunlosky, \& A. Graesser (Eds.), Metacognition in Educational Theory and Practice (pp. 277-304). Hillsdale, NJ: Lawrence Erlbaum.

Zimmerman, B. J. (2002). Becoming a self-regulated learner: An overview. Theory into Practice, 4l(2). https://doi.org/10.1207/s15430421tip4102_2 Perspectives (pp.1-37). Routledge Taylor \& Francis Group: New York London.

Zimmerman, B. (2001). Theories of self-regulated learning and academic achievement: An overview and analysis. In B. J. Zimmerman, \& D.H. Schunk (Eds.), Self Regulated Learning and Academic Achievement Theoretical Perspectives (pp.1-37). Routledge Taylor \& Francis Group: New York London.

Zimmerman, B. J. (1989). A Social cognitive view of self-regulated academic learning, Journal of Educational Psychology, 81(3), 329-339. https://doi.org/10.1037/0022-0663.81.3.329

Zimmerman, B. J. (1994). Dimensions of academic self-regulation: A conceptual framework for education. In D.H., Schunk; B. J. Zimmerman. (Eds.), Self-regulation of Learning and Performance Issues and Educational Applications (pp.3-21). Lawrence Erlbaum Associates: Hillsdale, New Jersey: Lawrence Erlbaum Associates.

Zimmerman, B. J. (2000). Attaining Self-regulation A social cognitive Perspective. M. Boekaerts and P.R. Pintrich (Eds.), Handbook Self-Regulation (pp. 13-40). Academic Press: San Diego San Francisco New York Boston London Sydney Tokyo.

Zimmerman, B. J. (2012). Goal setting: A key proactive source of academic self-regulation. In Schunk, D.H. \& Zimmerman, B.J. (Eds.), Motivation and Self-Regulated Learning Theory, Research, and Applications (pp.267-295). Routledge Taylor \&Francis Group: New York and London.

Zimmerman, B. J., \& Moylan, A. R. (2009). Self-regulation: where metacognition and motivation intersect. D. J. Hacker, J. Dunlosky, A. C., Graesser (Eds.), Handbook of Metacognition in Education (299-315). Routledge Taylor \& Francis Group: New York and London.

Zimmerman, B. J., \& Schunk, D. H. (1989). Self-regulated learning and academic achievement: Theory, research, and practice. New York: Springer-Verlag. https://doi.org/10.1007/978-1-4612-3618-4

Zimmerman, B. J., \& Schunk, D. H. (2001). Self-Regulated Learning and Academic Achievement. New York, NY: Springer-Verlag.

Zimmerman, B. J., \& Schunk, D. H. (2004). Self-regulating intellectual processes and outcomes: Social cognitive perspective. In D.Y. Dai, \& R.J. Stenberg (Eds.), Motivation, emotion, and cognition: Integrative perspectives on intellectual functioning and development (pp. 323-350). Mahwah, NJ: Erlbaum.

\section{Copyrights}

Copyright for this article is retained by the author(s), with first publication rights granted to the journal.

This is an open-access article distributed under the terms and conditions of the Creative Commons Attribution license which permits unrestricted use, distribution, and reproduction in any medium, provided the original work is properly cited. 